\title{
SEGURANÇA ALIMENTAR E AGROTÓXICOS: A situação do glifosato perante o princípio da precaução
}

José Cláudio Junqueira Ribeiro

Doutor em Saneamento, Meio Ambiente e Recursos Hídricos pela UFMG. Mestre em Saneamento e Urbanismo pela École Nacionale de La Santé Publique, Rennes (França). Especialista em Engenharia Sanitária pela UFMG. Graduação em Engenharia Civil pela Escola de Engenharia da UFMG. Professor do Mestrado em Direito Ambiental e Desenvolvimento Sustentável na Escola Superior Dom Helder Câmara. Professor Aposentado de Gestão Ambiental da Faculdade de Engenharia e Arquitetura da Universidade FUMEC. E-mail: jcjunqueira@yahoo.com.

Leonardo Cordeiro de Gusmão

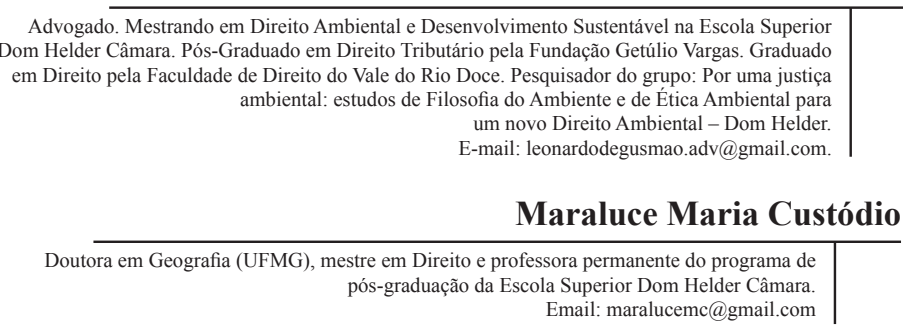

RESUMO

O presente trabalho utiliza do método jurídico de raciocínio dedutivo, com aplicação da técnica de pesquisa bibliográfica e documental. Nele, pretendese verificar se o Poder Público está sendo omisso no que tange à aplicação do Princípio da Precaução, sob a perspectiva da segurança alimentar, em relação à substância glifosato, que é o agrotóxico mais utilizado no Brasil, em especial nas monoculturas com cultivo de soja geneticamente modificada. A partir de resultados de estudos publicados pela Organização Mundial de Saúde, no qual foi qualificado como cancerígeno e causador de danos ao DNA e a cromossomos de células humanas, em conjunto com a deficiência de informações constantes no Programa de Análise de Resíduo de Agrotóxicos em Alimentos, publicado pela ANVISA, infere-se que pela existência de dúvida científica razoável se justificaria a aplicação de medidas de precaução, inclusive a proibição da utilização do glifosato na produção de alimentos no país, efetivando o direito à segurança do consumidor.

Palavras-chaves: Agrotóxico; Glifosato; Princípio da Precaução; Gestão de Riscos; Segurança Alimentar. 
FOOD SAFETY AND PESTICIDES: The situation of glyphosate before the Precautionary Principle

\section{ABSTRACT}

This article uses the legal method and deductive reasoning, with application of the bibliographical and documentary research technique. It intends to verify if there's any omission from Public Power regarding the application of the Precautionary Principle, at the from the perspective of food security, in relation to the substance glyphosate, which is the most used pesticide in Brazil, especially at the genetically modified soya crops. Based on results of studies published by World Health Organization which was qualified as carcinogenic and causing damage to the DNA and chromosomes of human cells, together with the deficiency of information contained in the Program Analysis of Pesticides Residues in Foods, put out by ANVISA, it is inferred that reasonable scientific uncertainty would justifies the application of precautionary measures, including the prohibition of the use of glyphosate in food production in the country, enforcing the right of consumer safety.

Keywords: Pesticide; Glyphosate; Precautionary Principle; Risk Management; Food Security. 


\section{INTRODUÇÃO}

O presente artigo pretende verificar, a partir do método jurídico de raciocínio dedutivo com pesquisa qualitativa, descritiva e explicativa, mediante uma análise bibliográfica e documental, se o Poder Público Federal brasileiro estaria sendo omisso no que tange à aplicação do Princípio da Precaução em relação à liberação do uso da substância glifosato, que é o agrotóxico mais utilizado no país, de modo a comprometer a segurança alimentar do consumidor.

O primeiro tópico tem o objetivo de delimitar os contornos da Sociedade de Risco, inserindo em tal contexto a Revolução Verde, evidenciando as consequências que a Revolução Industrial trouxe para a sociedade como um todo, com especial enfoque para os efeitos relacionados à utilização dos agrotóxicos na produção agrícola.

No tópico seguinte, tem-se como objetivo evidenciar o papel do Princípio da Precaução na gestão dos riscos incertos decorrentes da modernização das técnicas produtivas. Verificar-se-á, a previsão internacional do referido princípio, além de sua situação nos planos constitucional e infraconstitucional brasileiro, bem como o posicionamento do Supremo Tribunal Federal acerca de sua aplicabilidade e respectivas consequências.

No terceiro tópico será analisado o reconhecimento legal da periculosidade dos agrotóxicos pelo ordenamento jurídico brasileiro, especificando-se os tipos de intoxicação que tais substâncias podem causar ao consumidor. Será discutida, ademais, uma especificação do conteúdo do direito fundamental à alimentação adequada, averiguando-se também se há coerência nas conclusões obtidas pela ANVISA no Programa de Análise de Resíduos de Agrotóxicos publicado em 2016. Após, far-seá uma exposição acerca da aplicabilidade do Princípio da Precaução na gestão dos agrotóxicos.

Por fim, serão expostos estudos científicos publicados pela Organização Mundial de Saúde (OMS), relacionados à utilização do glifosato. Verificar-se-á se existe incerteza científica razoável em relação aos riscos que tal substância representa para a saúde humana, de modo a justificar a aplicação do Princípio de Precaução, evidenciando as possíveis consequências jurídicas e sociais, caso a resposta seja afirmativa. 


\section{SOCIEDADE (INDUSTRIAL) DE RISCO E REVOLUÇÃO VERDE}

A Revolução Industrial - iniciada no século XVIII, na Inglaterra - promoveu um rompimento com a cultura estamental da idade média. Deu início a uma nova era que se fundamentou na racionalidade científica e em constantes inovações tecnológicas, tidas como a solução para as mazelas da humanidade e como o caminho à concretização de seus anseios.

Contudo, evidenciou-se em 1.952, em Londres, a necessidade de se ponderar acerca dos riscos associados às inovações tecnológicas, por ocasião do desastre que ficou conhecido como "Black Smoke", em que milhares de pessoas morreram e outras tantas adoeceram em razão do excesso de fumaça gerada pela utilização de carvão como fonte de energia. De acordo com Ivan T. Berend "in a week when people could not see their own feet in the thick black smog, as many as 12,000 Londoners died and 100.000 became ill. Air pollution reached in intolerable level in the advanced industrialized world" (BEREND, 2006, p. 312).

$\mathrm{Na}$ segunda metade do século XX, os processos científicotecnológicos também alcançaram o setor agrícola na intenção de aumentar a produção, caracterizando o que se denominou como Revolução Verde, a qual se baseou em monoculturas de larga escala produzidas com o auxílio de máquinas e com a aplicação de agrotóxicos. De acordo com Douglas Gollin, Casper Worm Hansen e Asger Wingender "The Green Revolution emerged from philanthropic efforts - arguably shaped by geopolitical interests - to adress the challenges of rural poverty and agrarian unrest in the late $1950 \mathrm{~s}$ and early 1960s" (GOLLIN; HANSEN; WINGENDER,2016, p. 02).

Sob tal perspectiva, houve uma ampliação constante da utilização de monoculturas de larga escala que utilizavam maquinários e substâncias químicas destinadas a auxiliar no combate de "pragas", sob o propósito de maximizar a produção. Mais tarde adveio também, a partir da evolução das técnicas biotecnológicas, o desenvolvimento de sementes geneticamente modificadas resistentes a determinados produtos químicos, os quais passaram a ser aplicados cada vez com mais intensidade pelo setor agrícola.

Entretanto, essa modernização proporcionada pelas novas

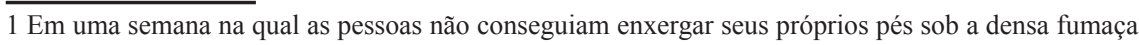
preta, cerca de 12.000 londrinos morreram e 100.000 ficaram doentes. A poluição do ar alcançou um nível intolerável no mundo industrializado moderno (tradução nossa).

2 A Revolução Verde formou-se a partir de esforços filantrópicos - indiscutivelmente moldados por interesses geopolíticos - para enfrentar os desafios da pobreza rural e da inquietação agrária ocorrida no final dos anos 50 e no início dos anos 60 (tradução nossa). 
tecnologias decorrentes do processo de industrialização - que foi de grande contribuição para o progresso social -, não foi acompanhada de uma capacidade científica capaz de prever de forma precisa a extensão de todos os seus efeitos colaterais. A sociedade industrializada do século XX e do início do século XXI passou a ser inserida num contexto de riscos muitas vezes invisíveis à comunidade científica, mas que nem por isso se tornavam menos ameaçadores.

Constituiu-se, portanto, o que Ülrich Beck denominou como Sociedade (industrial) de Risco, caracterizada por essa simbiose entre o desenvolvimento de novas tecnologias com a produção de riscos que quando se manifestam causam graves danos à saúde e à vida humana.

A fase de latência das ameaças do risco chega ao fim. As ameaças invisíveis tornam-se visíveis [...] Os balanços da presença de substâncias poluentes e tóxicas nos alimentos e nos bens de consumo tornam-se cada vez mais extensos. Os diques representados pelos limites máximos assemelham-se mais às exigências em relação ao queijo suíço (quanto mais buracos, melhor) do que às da proteção à saúde da população. As retratações desmentidas dos responsáveis fazem sempre mais barulho e apresentam menos argumentos (BECK, 2011, p. 66).

No contexto da produção de alimentos, Rachel Carson destacou, em sua obra "Primavera Silenciosa", a periculosidade resultante da utilização de agrotóxicos, salientando a origem bélica desses produtos químicos, cujos resíduos se impregnaram em toda parte do globo terrestre:

No período de menos de duas décadas desde que estão em uso, os pesticidas sintéticos foram tão amplamente distribuídos por todo o mundo animado e inanimado que se encontram praticamente em todos os lugares.

$[\ldots]$

Tudo isso veio a ocorrer devido à súbita ascensão e ao assombroso crescimento de uma indústria de produção de substâncias químicas artificiais ou sintéticas com propriedades inseticidas. Essa indústria é um dos frutos da Segunda Guerra Mundial. Durante o desenvolvimento de agentes para serem usados na guerra química, descobriu-se que algumas substâncias químicas criadas em laboratório eram letais aos insetos. A descoberta não ocorreu por acaso: os insetos já vinham sendo amplamente usados para testar substâncias químicas como agentes letais para os seres humanos (CARSON, 2010, p. 30).

Revela-se oportuno salientar que no Brasil, o Plano Nacional de 
Desenvolvimento Rural Sustentável - encampado pelo Decreto 8.735/16 - fez um alerta evidenciando os altos custos que essas novas práticas agrícolas trouxeram para o meio ambiente e para a sociedade:

\begin{abstract}
Na segunda metade de século XX, com a chamada "Revolução Verde", conseguiramse aumentos consideráveis de produção e de produtividade, com base na mecanização, uso de agroquímicos e monocultivos. Entretanto, hoje são computados altos custos ambientais e para a saúde, que representam custos econômicos também elevados.

A degradação dos solos - um quarto dos solos agricultáveis do mundo está em processo de degradação mais ou menos avançado - e o crescimento de áreas desertificadas, em decorrência de desmatamentos e práticas inadequadas de manejo do solo, são processos que tendem a se agravar com os avanços do aquecimento global. No caso da pesca, destaca-se a exploração excessiva a que a maioria dos recursos pesqueiros está submetida, além da degradação dos ambientes aquáticos, decorrente dos modelos de desenvolvimento rural e industrial preponderantes nas últimas décadas, que colocam em risco os estoques pesqueiros e representam uma ameaça também significativa à segurança alimentar mundial (BRASIL, 2013, p. 15).
\end{abstract}

Diante da necessidade de lidar com esse cenário de ameaças generalizadas e de incertezas quanto aos riscos socioambientais proporcionados pela Revolução Industrial - em que se insere a Revolução Verde -, as nações soberanas se organizaram internacionalmente no intuito de criar instrumentos capazes de gerenciar de modo adequado a situação, sem comprometer o desenvolvimento tecnológico e o crescimento econômico.

\title{
2 A GESTÃO DOS RISCOS IMPREVISÍVEIS MEDIANTE APLICAÇÃO PONDERADA DO PRINCÍPIO DA PRECAUÇÃO
}

Diante da imprevisibilidade dos riscos inerentes ao constante desenvolvimento científico-tecnológico, fez-se necessário o desenvolvimento de instrumentos jurídicos e políticos capazes de auxiliar na gestão de tais riscos. Com esse viés, por ocasião da Conferência das Nações Unidas sobre Meio Ambiente e Desenvolvimento, ocorrida na cidade do Rio de Janeiro em 1992 (Rio-92), assinalou-se a aplicação do princípio da precaução para as hipóteses em que houver dúvida científica razoável quanto aos riscos. 
Com o fim de proteger o meio ambiente, o princípio da precaução deverá ser amplamente observado pelos Estados, de acordo com suas capacidades. Quando houver ameaça de danos graves ou irreversíveis, a ausência de certeza científica absoluta não será utilizada como razão para o adiamento de medidas economicamente viáveis para prevenir a degradação ambiental (ONU, 1992).

No entanto, o referido princípio passou a ser interpretado de muitas maneiras distintas, nem sempre ponderada, ora com fundamento no medo que visa justificar uma restrição excessiva ao progresso econômico e tecnológico, outrora se baseando numa confiança temerária, priorizando o crescimento econômico e tratando tais riscos como uma espécie de mal necessário.

Sem dúvida, faz-se indispensável evitar os riscos de danos irreversíveis, contudo, a assunção de riscos é inerente à própria vida risco de morte - e indispensável ao progresso humano. Adequada, pois, a afirmação de Roger Scruton, segundo o qual os humanos "estão dispostos a arriscar a própria vida, defendendo um modo de vida que recusam abandonar" (SCRUTON, 2016, p. 114).

Convém ressaltar, aliás, que a capacidade inventiva que resulta na constante criação de novas tecnologias, é uma característica ínsita à humanidade, conforme assevera José Geraldo Freitas Drumond: "o homem é um ser tecnológico, pois desde a antiguidade sempre utilizou procedimentos e habilidades para melhor se adaptar ao seu habitat" (DRUMOND, 2007, p. 213).

Desse modo, a aplicação - política e/ou jurídica - do princípio da precaução deve ser norteada pelo balizamento dos interesses envolvidos, considerando circunstâncias fáticas peculiares que se apresentem. Somente assim será alcançado o desenvolvimento sustentável, que conforme salientado por Denise Schimitt Siqueira Garcia é composto por "três importantes dimensões: a ambiental, a social e a econômica" (GARCIA, 2016, p. 05).

No ordenamento jurídico brasileiro, o princípio da precaução está implícito no artigo 196 e artigo 225, §1 $1^{\circ}$ e incisos II, III, IV, V e VI, da Constituição da República Federativa do Brasil de 1.988 (CRFB/88), sendo aplicado não apenas para preservação do meio ambiente, mas também para proteger a sociedade contra os efeitos nocivos da degradação ambiental - como os danos à saúde. Esta compreensão foi adotada pelo Supremo Tribunal Federal (STF) por ocasião do julgamento da Ação Direta 
de Inconstitucionalidade (ADI) 3.510/DF, em 25/05/2008, conforme se observa em trecho do voto proferido pelo relator, o então Ministro Ayres de Britto:

Quando se cogita da preservação da vida numa escala mais ampla, ou seja, no plano coletivo, não apenas nacional, mas inclusive planetário, vem à baila o chamado "princípio da precaução", que hoje norteia as condutas de todos aqueles que atuam no campo da proteção do meio ambiente e da saúde pública. Ainda que não expressamente formulado, encontra abrigo nos arts. 196 e 225 de nossa Constituição (BRASIL, 2008, p. 32).

Entretanto, existe sua previsão expressa em normas infraconstitucionais, tais como o artigo 54, $\S 3^{\circ}$ da Lei 9.605/98; artigo $2^{\circ}$, inciso IV, do Decreto Federal 5.098/04; artigo $1^{\circ}$ da Lei 11.105/05 (BRASIL, 1998; 2004; 2005). Em razão da Teoria do Diálogo das Fontes, nada impede a comunicação normativa entre Leis Especiais, desde que não sejam incompatíveis e possibilitem uma maior efetivação de direitos fundamentais. Nesse sentido, há de se reconhecer o diálogo entre as normas mencionadas acima com a Lei 7.802/89, que traz a precaução apenas de modo implícito ao tratar de aspectos relacionados aos agrotóxicos.

Acerca da Teoria do Diálogo das Fontes, revela-se útil externar seus contornos nas palavras de Cláudia Lima Marques:

Em resumo, também entre leis especiais há diálogo das fontes: diálogo sistemático de coerência, diálogo sistemático de complementariedade ou subsidiariedade e diálogo de adaptação ou coordenação. Note-se que raramente é o legislador quem determina esta aplicação simultânea e coerente das leis especiais (um exemplo de diálogo das fontes ordenado pelo legislador é ao RT. 117 do CDC, que mandou aplicar o Título III do CDC aos casos da anterior Lei da Ação Civil Pública, Lei 7.347/1985 [...] (MARQUES, 2016, p. 147)

Mais recentemente - 08/06/2016 -, ao reconhecer em a Repercussão Geral no julgamento do Recurso Extraordinário(RE) 627.189SP, o Supremo Tribunal Federal, sob a relatoria do Ministro Dias Toffoli, reconheceu a relevância da aplicação do princípio da precaução em situações de incerteza científica devidamente fundamentada, afirmando, inclusive, que tal dúvida pode servir até mesmo ao questionamento jurisdicional de políticas públicas. 
[...] O princípio da precaução é um critério de gestão de risco a ser aplicado sempre que existirem incertezas científicas sobre a possibilidade de um produto, evento ou serviço desequilibrar o meio ambiente ou atingir a saúde dos cidadãos, o que exige que o estado analise os riscos, avalie os custos das medidas de prevenção e, ao final, execute as ações necessárias, as quais serão decorrentes de decisões universais, não discriminatórias, motivadas, coerentes e proporcionais. 3. Não há vedação para o controle jurisdicional das políticas públicas sobre a aplicação do princípio da precaução, desde que a decisão judicial não se afaste da análise formal dos limites desses parâmetros e que privilegie a opção democrática das escolhas discricionárias feitas pelo legislador e pela Administração Pública [...] (BRASIL, 2016, s/p, entre colchetes nossos).

O princípio da precaução se constitui, portanto, como ferramenta indispensável ao atendimento das exigências constantes no artigo 170, III e VI e artigo 225, ambos da CRFB/88. Conclui-se, assim, que sua aplicação deve ser orientada por uma dúvida científica razoável quanto aos riscos, estabelecida dentro de certos limites, de modo a promover uma ponderação entre as dimensões econômica, social e ambiental do desenvolvimento sustentável.

Importante, ademais, realçar o óbvio: a existência da dúvida científica razoável depende da realização de estudos acerca de determinada prática, aplicando-se as metodologias indispensáveis à obtenção de um resultado, o qual poderá ser ou não conclusivo. A inércia científica no que concerne à verificação dos riscos relacionados a uma substância ou tecnologia torna inviável a aplicação do princípio da precaução, aniquilando-o de modo a prejudicar a gestão dos riscos socioambientais.

No tópico seguinte far-se-á uma verificação do tratamento jurídico brasileiro dado aos agrotóxicos, relacionando-o com o objetivo nacional de se garantir segurança alimentar à sociedade. Posteriormente, serão apresentadas as conclusões da Agência Nacional de Vigilância Sanitária (ANVISA), no que diz respeito aos riscos inerentes ao consumo de frutas, verduras e hortaliças cultivadas mediante aplicação de agrotóxicos. 


\title{
3 SEGURANÇAALIMENTAR NO BRASIL A PARTIR DAANÁLISE DE RESÍDUOS DE AGROTÓXICOS NOS ALIMENTOS
}

A efetivação da segurança alimentar é objetivo nacional que se presta à garantia da dignidade da pessoa humana. Para sua realização torna-se imprescindível assegurar a fruição do direito fundamental à alimentação adequada, o qual está previsto no artigo $6^{\circ}$ da CRFB $/ 88$ e no artigo $2^{\circ}$ da Lei 11.346/06. Segundo a Política Nacional de Alimentação e Nutrição (PNAN), o conteúdo do referido direito envolve tanto aspectos quantitativos quanto qualitativos:

\begin{abstract}
Alimentação adequada e saudável: prática alimentar apropriada aos aspectos biológicos e socioculturais dos indivíduos, bem como ao uso sustentável do meio ambiente. Deve estar de acordo com as necessidades de cada fase do curso da vida e com as necessidades alimentares especiais; ser referenciada pela cultura alimentar e pelas dimensões de gênero, raça e etnia; ser acessível do ponto de vista físico e financeiro; harmônica em quantidade e qualidade; baseada em práticas produtivas adequadas e sustentáveis; com quantidades mínimas de contaminantes físicos, químicos e biológicos. (BRASIL, 2013, p. 68)
\end{abstract}

Tais dizeres estão em plena consonância com o Comentário Geral $n^{\circ} 12$, que faz menção ao art. 11 do Pacto Internacional dos Direitos Econômicos, Sociais e Culturais, organizado no âmbito da Organização das Nações Unidas (ONU), o qual foi incorporado ao ordenamento jurídico brasileiro pelo Decreto 591/92. Nele, destaca-se a necessidade de se interpretar o direito à alimentação de forma ampliativa, não podendo seu conteúdo ficar restrito a um pacote mínimo de nutrientes específicos, devendo ser efetivado de forma progressiva - proibindo-se o retrocesso e impondo uma evolução nas respectivas políticas públicas.

O direito à alimentação adequada realiza-se quando cada homem, mulher e criança, sozinho ou em companhia de outros, tem acesso físico e econômico, ininterruptamente, à alimentação adequada ou aos meios para sua obtenção. O direito à alimentação adequada não deverá, portanto, ser interpretado em um sentido estrito ou restritivo, que o equaciona em termos de um pacote mínimo de calorias, proteínas e outros nutrientes específicos. O direito à alimentação adequada terá de ser resolvido de maneira progressiva. No entanto, os estados têm a obrigação precípua de implementar as ações necessárias para mitigar e aliviar a fome, como estipulado 
no parágrafo 2 do artigo 11, mesmo em épocas de desastres, naturais ou não. (ONU, 1999, p. 02)

Pode-se afirmar, portanto, que o direito à alimentação adequada consiste na garantia de acesso a alimentos em quantidade e qualidade condizentes com as características biológicas e culturais de cada indivíduo, não se limitando à oferta de valores nutricionais mínimos, abrangendo também a necessidade de se reduzir continuamente os riscos proporcionados por contaminantes físicos, químicos e biológicos.

Nesse contexto, fator relevante a ser analisado é o nível de resíduos químicos presentes nos alimentos ingeridos pelos consumidores. De acordo com relatório publicado pela ONU em 2017, concernente à segurança alimentar, os agrotóxicos representam um grande risco à saúde dos consumidores, que são diariamente expostos a múltiplos resíduos:

Pesticide residues are commonly found in both plant and animal food sources, resulting in significant exposure risks for consumers. Studies indicate that foods often contain multiple residues, thereby resulting in the consumption of a "cocktail" of pesticides. Although the harmful effects of pesticide mixtures are still not fully understood, it is known that in some cases, synergistic interactions can occur that lead to higher toxicity levels 3 (ONU, 2017, p. 08).

Faz-se mister salientar que de acordo com informações prestadas pela Associação Brasileira de Saúde Coletiva (ABRASCO, 2015, p. 17), desde o ano de 2008 o Brasil é o país que mais consome agrotóxicos em todo o mundo. Essa excessiva utilização de agrotóxicos causa impactos negativos à saúde de distintos grupos populacionais, como trabalhadores do campo, moradores de regiões que rodeiam fábricas e fazendas e também aos consumidores.

Segundo o Sistema Nacional de Informações Tóxico - Farmacológicas - SINITOX, criado em 1980 e vinculado à Fundação Oswaldo Cruz - FIOCRUZ - são milhares os registros de intoxicação humana e envenenamento no país (FIOCRUZ, 2016).

Neice Faria, Anaclaudia Fassa e Luiz Facchini analisaram os

3 Resíduos de agrotóxicos são comumente encontrados em alimentos de origem vegetal e animal, expondo os consumidores a riscos significantes. Estudos indicam que os alimentos geralmente contêm múltiplos resíduos, acarretando, assim, no consumo de um "cocktail" de agrotóxicos. Embora os efeitos nocivos da mistura de agrotóxicos ainda não sejam totalmente compreendidos, é sabido que em alguns casos podem ocorrer interações sinérgicas que levam a maiores níveis de toxidade (tradução nossa). 
casos de intoxicação por agrotóxicos no Brasil, e relatam que "o trabalho agrícola é uma das mais perigosas ocupações na atualidade, destacando os agrotóxicos que são relacionados a intoxicações agudas, doenças crônicas, problemas reprodutivos e danos ambientais (FARIA et al., 2007, p. 26).

De acordo com o Manual de Vigilância da Saúde de Populações Expostas a Agrotóxicos, elaborado em 1996 pela Organização Pan-Americana de Saúde (OPAS) e Organização Mundial de Saúde (OMS), são três os tipos possíveis de intoxicação que podem ser causados por agrotóxicos:

Os agrotóxicos podem determinar três tipos de intoxicação: aguda, subaguda e crônica. Na intoxicação aguda os sintomas surgem rapidamente, algumas horas após a exposição excessiva, por curto período, a produtos extrema ou altamente tóxicos. Pode ocorrer de forma leve, moderada ou grave, a depender da quantidade de veneno absorvido. Os sinais e sintomas são nítidos e objetivos.

A intoxicação subaguda ocorre por exposição moderada ou pequena a produtos altamente tóxicos ou medianamente tóxicos e tem aparecimento mais lento. Os sintomas são subjetivos e vagos, tais como dor de cabeça, fraqueza, mal-estar, dor de estômago e sonolência, entre outros.

A intoxicação crônica caracteriza-se por surgimento tardio, após meses ou anos, por exposição pequena ou moderada a produtos tóxicos ou a múltiplos produtos, acarretando danos irreversíveis, do tipo paralisias e neoplasias (OPAS; OMS, 1996, p. 23).

Evidente, portanto, que o direito à alimentação adequada e a conquista da segurança alimentar são fatores intimamente relacionados com a efetivação do direito fundamental à saúde, previsto no artigo $6^{\circ} \mathrm{e}$ 196 da CRFB/88. Ademais, evidencia-se a relevância da análise e controle de resíduos de agrotóxicos presentes nos alimentos ingeridos pelos consumidores.

Há de se ressaltar, ademais, que a periculosidade inerente aos agrotóxicos é reconhecida constitucionalmente pelo artigo $220, \S 3^{\circ}$, inciso II e $\S 4^{\circ}$, que preocupado com a saúde da população, impõe o estabelecimento de restrições às propagandas envolvendo a tais substâncias químicas, assim como o fez em relação ao tabaco e às bebidas alcoólicas e medicamentos (BRASIL, 1988).

No âmbito infraconstitucional, merece destaque o artigo $3^{\circ}, \S 6^{\circ}$, alíneas $\mathrm{C}$, D e F, e artigo $7^{\circ}$, inciso I, alínea $\mathrm{H}$, ambos da Lei 7.802/89; 
que além de exigir a prestação de informações acerca da classificação toxicológica de cada substância em seu rótulo, impõem a proibição de registro de agrotóxicos que possuem características carcinogênicas ou mutagênicas, que provoquem distúrbios hormonais ou danos ao aparelho reprodutor (BRASIL, 1989).

Atente-se que esse dever de cuidado visa proteger não apenas o produtor rural que faz o manejo de agrotóxicos utilizados na lavoura, mas também os consumidores dos alimentos que contêm os respectivos resíduos, garantindo-lhes os direitos à informação e à segurança contra produtos nocivos à saúde, por determinação do artigo $6^{\circ}$, incisos I e III, da Lei 8.078/90 - Código de Defesa do Consumidor (CDC) -; do artigo $2^{\circ}$, § $2^{\circ}$ e $\S 4^{\circ}$, incisos III, IV, V e VI da Lei 11.346/06; e do artigo $2^{\circ}$, inciso I e II, do Decreto 5.098/04 (BRASIL, 1990; 2004; 2006).

Relevante atentar que o Manual de Vigilância da Saúde de Populações Expostas a Agrotóxicos faz uma ressalva quanto à análise de segurança decorrente da ingestão dessas substâncias químicas, salientando que vários são os fatores que podem contribuir para uma eventual intoxicação. Os estudos científicos pertinentes não podem se limitar à verificação da toxidade de uma substância isolada, devendo reconhecer também as peculiaridades do organismo de cada indivíduo e o fato de que a sociedade está exposta ao contato com múltiplas substâncias. Ademais, há uma grande dificuldade metodológica no que tange à estipulação de um diagnóstico acerca da intoxicação crônica.

Essas intoxicações não são reflexo de uma relação simples entre o produto e a pessoa exposta. Vários fatores participam de sua determinação, dentre eles os fatores relativos às características químicas e toxicológicas do produto, fatores relativos ao indivíduo exposto, às condições de exposição ou condições gerais do trabalho.

Características do produto: características toxicológicas, forma de apresentação, estabilidade, solubilidade, presença de contaminantes, presença de solventes, etc.

Características do indivíduo exposto: idade, sexo, peso, estado nutricional, escolaridade, conhecimento sobre os efeitos a medidas de segurança, etc.

Condições de exposição: condições gerais do trabalho, freqüência, dose, formas de exposição, etc.

As características clínicas das intoxicações por agrotóxicos dependem, além dos aspectos acima citados, do fato de ter ocorrido contato/exposição a um único tipo de produto ou a vários deles. Nas intoxicações agudas decorrentes do contato/exposição a apenas um produto, os sinais e sintomas clínico-laboratoriais são bem conhecidos, 
o diagnóstico é claro e o tratamento definido. Em relação às intoxicações crônicas, o mesmo não pode ser dito. O quadro clínico é indefinido e o diagnóstico difícil de ser estabelecido (OPAS; OMS, 1996, p. 23).

Ao se considerar que o Brasilé o maior consumidor de agrotóxicos do mundo e os graves danos à saúde provocados por intoxicações decorrentes do consumo de alimentos com resíduos químicos, além da dificuldade em estipular a possibilidade de sua ocorrência - em especial a intoxicação crônica -, revela-se imprescindível uma cuidadosa e contínua fiscalização dos alimentos comercializados, com aplicação do Princípio da Precaução.

No que concerne aos cuidados com a segurança alimentar, a autoridade competente para verificar possíveis riscos ofertados por resíduos tóxicos presentes em alimentos é a Agência Nacional de Vigilância Sanitária (ANVISA), uma vez que o artigo $8^{\circ}, \S 1^{\circ}$, inciso II, da lei 9.782/99 lhe atribuiu obrigação de regulamentar, controlar e fiscalizar produtos que acarretem em risco à saúde, ao passo que o artigo $6^{\circ}$, inciso I do Decreto 4.074/02 conferiu competência para realizar a avaliação e classificação toxicológica de agrotóxicos (BRASIL, 1999; 2002).

No ano de 2016 a ANVISA disponibilizou sua última análise de resíduos de agrotóxicos em alimentos, compreendendo amostras coletadas entre os anos de 2013 e 2015. Foram pesquisados 232 tipos de agrotóxicos nas amostras monitoradas, das quais, segundo as conclusões da agência, $80,3 \%$ apresentaram resultados satisfatórios, sendo que $42 \%$ não apresentaram resíduos dos agrotóxicos pesquisados e 38,3\% apresentaram resíduos dentro dos limites estipulados (ANVISA, 2016, p. 05).

Importante atentar que a análise em questão não considerou todos os tipos de agrotóxicos registrados e utilizados no país, presumindo como satisfatórias as amostras nas quais não se encontraram resíduos daquelas substâncias específicas que foram analisadas - as quais poderiam conter outras substâncias, não analisadas. (ANVISA, 2016, p. 05).

Do total das amostras monitoradas, 9.680 amostras (80,3\%) foram consideradas satisfatórias, sendo que 5.062 destas amostras (42,0\%) não apresentaram resíduos dentre os agrotóxicos pesquisados e 4.618 (38,3\%) apresentaram resíduos de agrotóxicos dentro do LMR. Foram consideradas insatisfatórias 2.371 amostras (19,7\%), sendo que 362 destas amostras (3,00\%) apresentaram concentração de resíduos acima do LMR e 2.211 (18,3\%) apresentaram resíduos de agrotóxicos não autorizados para a cultura (ANVISA, 2016). 
No que tange à metodologia adotada para avaliar o risco de intoxicação aguda, a análise da ANVISA teve como pressuposto de que é improvável que um indivíduo consuma uma grande quantidade de dois ou mais tipos de alimentos diferentes, em um curto período de tempo, contendo resíduos de agrotóxico em concentrações excessivas. Sob tal perspectiva, concluiu que o nível de segurança alimentar no Brasil é aceitável no que se refere aos potenciais riscos de intoxicação aguda advindos da exposição dietética aos resíduos de agrotóxicos. Afirmou-se que apenas 1,11\% dos alimentos pesquisados demonstraram potencial risco agudo à saúde (ANVISA, 2016, p. 06).

Em relação ao risco de intoxicação crônica, limitou-se a fazer menção à análise realizada em 2013, na qual se afirmou que o risco à saúde era considerado aceitável, uma vez que à luz do conhecimento atual, na maior parte dos casos seria necessário o consumo diário, durante anos, de vários alimentos contendo uma quantidade de determinado agrotóxico sempre superior aos limites máximos estabelecidos. No entanto frisou que não se pode descartar a possibilidade de riscos crônicos à saúde em razão da dieta (ANVISA, 2016, p. 105).

Diante dessa reconhecida incerteza no que diz respeito à intoxicação crônica - cujos efeitos se manifestam meses ou anos depois -, revela-se útil trazer à tona o conteúdo do direito fundamental à saúde, elaborado por Paulo Affonso Leme Machado:

A saúde dos seres humanos não existe somente numa contraposição a não ter doenças diagnosticadas no presente. Leva-se em conta o estado dos elementos da Natureza - águas, solo, ar, flora, fauna e paisagem - para se aquilatar se esses elementos estão em estado de sanidade e de seu uso advenham saúde ou doenças e incômodos para os seres humanos (MACHADO, 2016, p. 70).

A previsão constitucional do direito fundamental à saúde, portanto, obriga o Poder Público a adotar medidas de precaução que visem evitar o envenenamento gradativo capaz de causar doenças no futuro doenças crônicas. De acordo com o Instituto Nacional do Câncer (INCA), a intoxicação crônica resultante do consumo de agrotóxicos pode acarretar em diversos problemas à saúde humana, tais como: infertilidade, impotência, abortos, malformações, neurotoxidade, desregulação hormonal, efeitos sobre o sistema imunológico e câncer (INCA, 2015, p. 03).

Em relação à intoxicação subaguda a análise da ANVISA não faz 
qualquer manifestação, podendo-se presumir que considera apenas dois tipos de intoxicação por agrotóxicos: intoxicação aguda - com efeitos num curto período de tempo - e crônica - com efeitos tardios.

O documento também informa que a avaliação da exposição aos resíduos de agrotóxicos pela dieta foi realizada considerando-se a exposição a um único ingrediente ativo por vez, embora reconheça que alguns agrotóxicos possuem o mesmo mecanismo de ação tóxica, podendo ensejar num efeito aditivo no organismo $\square$ bioacumulação (ANVISA, 2016, p. 106).

Não se fez qualquer menção à possibilidade de interação química entre substâncias distintas $\square$ devido ao "cocktail” de múltiplos agrotóxicos presentes em alguns alimentos $\square$ e também não houve uma expressa alusão ao fato de que, no final das contas, qualquer conclusão seria meramente estimativa, uma vez que o organismo de cada indivíduo reage de modo distinto face ao contato com determinada substância química ou com várias delas associadas.

Em razão dos parâmetros utilizados pela ANVISA, pode-se dizer que os resultados apresentados são insuficientes para garantir segurança em relação à intoxicação aguda, haja vista que não houve a análise de todos agrotóxicos autorizados, efetivamente utilizados nas lavouras e presentes nos alimentos ingeridos pelos consumidores. Por sua vez, em relação à intoxicação crônica a conclusão foi imprecisa, admitindo-se posteriormente a incerteza quanto aos riscos.

Pode-se considerar, portanto, que o nível de segurança alimentar no Brasil - maior consumidor de agrotóxicos do mundo - é incerto, tendo em vista a insuficiência da avaliação do risco de intoxicação aguda. Além disso, as lacunas existentes na comunidade científica no tocante à intoxicação crônica pelos efeitos acumulativos de determinadas substâncias aumentam as incertezas sobre os riscos de efeitos sinérgicos pela reação química dos resíduos dos distintos agrotóxicos presentes nos alimentos e pela diversidade de reações inerentes ao organismo de cada indivíduo.

Devido ao aumento contínuo da utilização de agrotóxicos no país, evidencia-se também o crescente descumprimento da obrigação de se garantir de forma progressiva o direito fundamental à alimentação adequada. Faz-se mister salientar, ainda, que de acordo com a ANVISA, o resultado obtido pelo documento não serve como ferramenta útil à prestação de informação aos consumidores, no que se refere aos riscos iminentes à alimentação, uma vez que a análise foi realizada após o consumo dos 
alimentos (ANVISA, 2016, p. 06).

Observa-se, portanto, que a ANVISA concluiu que o nível de agrotóxicos presentes nos alimentos consumidos pelos brasileiros é satisfatório, apesar de uma análise insuficiente da intoxicação aguda e de ter admitido que em relação à intoxicação crônica o grau de segurança é meramente especulativo.

Conforme já destacado anteriormente, devido ao vínculo indissociável existente entre a preservação ambiental e dignidade humana, a aplicação do Princípio da Precaução não se limita à proteção do meio ambiente em si, devendo ser utilizado também no intuito de proteger a sociedade contra os efeitos nocivos que os danos ambientais representam para sua saúde.

Neste tópico, portanto, foram realizadas as ponderações necessárias acerca dos riscos que os agrotóxicos em geral representam para o meio ambiente e para a saúde humana, além de se evidenciar a necessidade de aplicação do Princípio da Precaução. Adiante, será feita uma abordagem específica em relação à substância glifosato.

\section{ASITUAÇÃO DO GLIFOSATO NO CENÁRIO INTERNACIONAL E BRASILEIRO}

Em princípio faz-se pertinente frisar que de acordo com a ABRASCO, o glifosato representa sozinho, $40 \%$ do total de agrotóxicos utilizados na produção agrícola brasileira, sendo o Brasil o maior consumidor de agrotóxicos do mundo (ABRASCO, 2015, p. 80). No registro de monografias autorizadas pela ANVISA, informa-se que se trata de substância da classe herbicida - combate plantas invasoras - e sua classificação toxicológica é de nível IV (ANVISA, 2017, s/p).

Trata-se de substância química cuja aplicação deve ocorrer em caráter pós-emergencial nas plantas invasoras das seguintes culturas: algodão, ameixa, arroz, banana, cacau, café, cana-de-açúcar, citros, coco, feijão, fumo, maçã, mamão, milho, nectarina, pastagem, pêra, pêssego, seringueira, soja, trigo e uva. (ANVISA, 2017, s/p).

Importante asseverar que anteriormente, a aplicação do "Glifosato" ocorria apenas antes do nascimento da planta (pré-emergente), sendo que nos dias atuais, conforme informado no parágrafo anterior, a ANVISA permite sua aplicação pós-emergente, isto é, depois do nascimento da planta: "O glifosato (Roundup Ready) tinha seu registro limitado ao uso 
pré-emergente, ou seja, anterior ao nascimento da planta, e, portanto, não poderia ser usado na fase pós-emergente" (VAZ, 2006, p. 58).

Segundo a ABRASCO, o aumento constante na utilização de agrotóxicos no Brasil, no decorrer da última década, deve-se principalmente à expansão do cultivo da soja transgênica e à resistência adquirida pelas plantas daninhas combatidas mediante aplicação do glifosato (ABRASCO, 2015, p. 52).

Quanto à atuação do glifosato no combate de plantas invasoras prejudiciais à produção agrícola, vale mencionar trecho da tese de doutorado produzida por Maria Olandina Machado: "Explicando de forma simplificada o processo, podemos dizer que o glifosato impede a produção de aminoácidos essenciais na produção de proteínas, sem as quais a planta morre" (MACHADO, 2016, p. 84).

Já no que se refere à definição dos parâmetros de segurança relativos à quantidade de resíduos de glifosato que podem ser encontrados nos alimentos, a autora ressalta a situação do cultivo da soja geneticamente modificada, em que houve um grande aumento no que tange ao limite máximo estabelecido como condição para preservação do meio ambiente e da saúde humana.

É importante notar que a soja comum até 2002 tinha o limite estabelecido em 0,2 $\mathrm{mg} / \mathrm{kg}$. Quando da introdução da soja GM houve o estabelecimento de LMR de 2,0 $\mathrm{mg} / \mathrm{kg}$, diferente da soja comum. E a partir de 2002 os LMRs foram fixados em $10 \mathrm{mg} / \mathrm{kg}$. Os grupos contrários evidenciavam sobre o percentual de aumento dos limites, em torno de 50 vezes (MACHADO, 2016, p. 154).

Intrigada com esse aumento vertiginoso dos limites de resíduos do glifosato, Larissa Mies Bombardi comparou os parâmetros de segurança estabelecidos no Brasil e na União Europeia, no que diz respeito às plantações de soja, café e cana-de-açúcar:

No caso do Glifosato, o resíduo permitido (LMR) no Brasil no café, por exemplo, é dez vezes maior do que aquele permitido na União Europeia (respectivamente 1 $\mathrm{mg} / \mathrm{kg}$ e $0,1 \mathrm{mg} / \mathrm{kg})$.

Para o caso da cana-de-açúcar o máximo de resíduo permitido de Glifosato no Brasil é 20 vezes maior do que na União Europeia $(0,05 \mathrm{mg} / \mathrm{kg}$ na UE e $1 \mathrm{mg} / \mathrm{kg}$ no Brasil).

No caso da soja, esta comparação quantifica a expressão "assimetria" das diferenças entre Brasil e União Europeia quanto à "permissividade de resíduos de agrotóxicos. 
Na soja brasileira é permitido um resíduo de glifosato 200 (duzentas) vezes maior do que aquele permitido na União Europeia, $(0,05 \mathrm{mg} / \mathrm{kg}$ na UE e $10 \mathrm{mg} / \mathrm{kg}$ no Brasil) (BOMBARDI, 2017, p. 50).

O problema relacionado ao glifosato não se limita ao fato de se tratar no agrotóxico mais utilizado no Brasil e nem na assimetria relativa aos parâmetros de segurança, se comparados com aqueles estabelecidos pela União Europeia. Reside, especialmente, nas conclusões resultantes de estudos realizados pela Agência Internacional de Pesquisa em Câncer (IARC, em inglês), vinculada à Organização Mundial de Saúde (WHO, em inglês), publicados no ano de 2015. Constatou-se que a substância possui potencial cancerígeno em seres humanos, além de causar danos ao DNA e cromossomos de células humanas.

The herbicide glyphosate and the insecticides malathion and diazinon were classified as probably carcinogenic to humans (Group 2A).

$[\ldots]$

The IARC Working Group that conducted the evaluation considered the significant findings from the US EPA report and several more recent positive results in concluding that there is sufficient evidence of carcinogenicity in experimental animals. Glyphosate also caused DNA and chromosomal damage in human cells, although it gave negative results in tests using bacteria. One study in community residents reported increases in blood markers of chromosomal damage (micronuclei) after glyphosate formulations were sprayed nearby ${ }^{4}$ (IARC, 2015, p. 01).

Ao se manifestar sobre o resultado da análise, a ANVISA declarou que prosseguiria com a reavaliação toxicológica do glifosato, contudo, disse que outras substâncias teriam prioridade, pois de acordo com a Fundação Oswaldo Cruz (FIOCRUZ) - com quem firmou convênio - as evidências obtidas pelo IARC eram insuficientes, exigindo a realização de novos estudos.

$4 \mathrm{O}$ herbicida glifosato e os inseticidas malation e diazinon foram classificados como potencialmente cancerígenos a humanos (Grupo 2A).

$[\ldots]$

O grupo de trabalho do IARC que conduziu a avaliação considerou significativas as conclusões contidas no relatório da EPA dos EUA e em vários resultados positivos mais recentes, no sentido de que há evidência suficiente da carcinogenicidade em experimentos animais. O Glifosato também causa danos ao DNA e aos cromossomos das células humanas, embora os resultados tenham sido negativos em testes utilizando bactérias. Um estudo em residentes de uma comunidade relatou aumentos em marcadores sanguíneos de danos cromossômicos (micronúcleos) depois da pulverização sistemática de glifosato em seus arredores. (tradução nossa) 
- Glifosato

O glifosato, que também foi classificado como provável carcinógeno em humanos pela IARC, é um herbicida de largo espectro, que, na atualidade, possui os maiores volumes de produção dentre todos os herbicidas. O agrotóxico é usado na agricultura, na silvicultura, em áreas urbanas e domésticas. Seu uso tem aumentado consideravelmente com o desenvolvimento de variedades de culturas geneticamente modificados resistentes a ele. Para o prosseguimento da reavaliação do glifosato e dos demais agrotóxicos cuja reavaliação está prevista na RDC, a Anvisa firmou um contrato com a Fiocruz. A instituição ficou responsável pela elaboração das notas técnicas para cada um dos ingredientes ativos, as quais devem ser revisadas pelo corpo técnico da Anvisa antes de serem publicadas. Na análise dessas notas técnicas pela Anvisa, foram observadas necessidades de revisão e, desta forma, estabeleceu-se uma ordem de análise dessas notas técnicas, de acordo com os indícios de toxicidade apontados pela Fiocruz. A conclusão da reavaliação do glifosato não foi considerada prioritária pela Anvisa, considerando-se que, ao contrário do que ocorreu com outros ingredientes ativos, a Fiocruz não indicou seu banimento. A Fundação conclui somente que as evidências de mutagenicidade, carcinogenicidade e desregulação endócrina deste ingrediente ativo eram insuficientes e indicando a necessidade de novos estudos (ANVISA, 2015, s/p).

Portanto, apesar do alerta realizado no ano de 2015 pelo instituto de pesquisa de câncer vinculado à organização mundial de saúde, não houve qualquer modificação no tange à utilização da substância no Brasil. Tal situação foi ressaltada em documento publicado pelo Ministério Público Federal (MPF), no qual se ressaltou a inércia no que tange à adoção de medidas de precaução em relação à substância.

O Glifosato nasceu junto com a soja transgênica, que foi desenvolvida para ser resistente a ele. Os testes em animais para sua liberação foram realizados pelas próprias empresas interessadas e duraram apenas 3 meses. Testes realizados em período superior causaram tumores e alterações metabólicas intensas. Segundo o levantamento bibliográfico realizado pela professora, o Glifosato está ligado a desordens gastrointestinais, obesidade, diabetes, doenças cardíacas, depressão, infertilidade, câncer, Mal de Alzheimer, Mal de Parkinson, intolerância ao glúten.

No Brasil, é considerada potável a água com menos de 500 microgramas de Glifosato por litro. Todavia, nos testes para sua liberação a dosagem usada foi de 1 micrograma. Em março de 2015, o IARC (Agência Internacional de Pesquisa em Câncer) declarou que o Glifosato é um provável cancerígeno, motivo pelo qual diversas autoridades, 

nenhuma mudança (MPF, 2017, p. 02).

Já no ano de 2016, a Organização Mundial de Saúde, a partir de estudos realizados pela Organização das Nações Unidas para a Agricultura e a Alimentação (FAO, em inglês), publicou novo comunicado em sentido contrário àquele do ano de 2015 emitido pela Agência Internacional de Pesquisa em Câncer. Afirmou ser improvável que o consumo de alimento com resíduos de glifosato cause câncer a seres humanos.

The Meeting concluded that glyphosate is unlikely to be genotoxic at anticipated dietary exposures. Several carcinogenicity studies in mice and rats are available. The Meeting concluded that glyphosate is not carcinogenic in rats but could not exclude the possibility that it is carcinogenic in mice at very high doses. In view of the absence of carcinogenic potential in rodents at human-relevant doses and the absence of genotoxicity by the oral route in mammals, and considering the epidemiological evidence from occupational exposures, the Meeting concluded that glyphosate is unlikely to pose a carcinogenic risk to humans from exposure through the $\operatorname{diet}^{5}$. (WHO; FAO, 2016, p. 02)

Deve-se observar que as duas declarações fizeram conclusões de probabilidade - em 2015 a Organização Mundial de Saúde afirmou que o glifosato é potencialmente cancerígeno e capaz de causar danos ao DNA e a cromossomos de células humanas, enquanto que em 2016 disse ser improvável que a substância causasse câncer -, não confirmando ou desmentindo de forma absoluta o caráter nocivo do glifosato.

A situação exposta no parágrafo anterior é típica da sociedade de risco e, dado que se trata de manifestações contraditórias propagadas pela principal instituição internacional de cuidado com a saúde humana - Organização Mundial de Saúde -, pode-se dizer que há uma dúvida científica razoável que justifica a imposição de medidas de precaução. Tal situação enquadra-se na situação mencionada por Paulo de Bessa Antunes: "the doubt about the harmful nature of a substance should not

$5 \mathrm{O}$ encontro concluiu ser improvável que o glifosato seja genotóxico em exposições alimentares. Vários estudos de carcinogenicidade em camundongos e ratos estão disponíveis. O encontro concluiu que o glifosato não é cancerígeno em ratos, mas não excluiu a possibilidade da carcinogenicidade em camundongos mediante doses muito altas. Tendo em vista a ausência de potencial cancerígeno em roedores sob doses relevantes ao ser humano, a ausência de genotoxidade por via oral em mamíferos, e considerando as evidências epidemiológicas de exposições ocupacionais, o encontro concluiu que o glifosato não é suscetível de apresentar risco de câncer para os seres humanos em razão da exposição através da dieta. (tradução nossa) 
be interpreted as if there was no risk. However, risks have to be identified based on scientific information, with suitable protocols" (ANTUNES, 2016, p. 73).

Tais medidas podem variar, consistindo na realização de estudos de análise de toxidade, na prestação de informações de advertência ao consumidor e até mesmo na proibição da utilização do produto químico com base no artigo $3^{\circ}, \S 6^{\circ}$, alíneas C e D, da Lei 7.802/89 e art. 31, incisos III, IV, V e VI, do Decreto 4.074/02 (BRASIL, 1989; 2002).

Não bastasse tudo isso, atualmente se observa um movimento do Poder Legislativo na intenção de omitir as poucas informações prestadas ao consumidor, capazes de possibilitar que eles identifiquem produtos que contêm resíduos de glifosato, exercendo sua autonomia quanto aos riscos associados.

A afirmação realizada no parágrafo anterior se fundamenta no Projeto de Lei da Câmara dos Deputados (PLC) 34/2015, aprovado pela Comissão de Meio Ambiente do Senado Federal em 17/04/2018, que tem como objetivo a retirada do triângulo amarelo com a letra $\mathrm{T}$ das embalagens de produtos que contêm alimentos geneticamente modificados, os quais em sua maioria são cultivados com aplicação de glifosato (SENADO FEDERAL, 2018).

Vale ressaltar que em $25 / 09 / 2013$, por ocasião do julgamento do Mandado de Segurança (MS) 20.457/DF sob a relatoria do Ministro Herman Benjamin, o Superior Tribunal de Justiça (STJ) se manifestou no sentido de que os direitos à saúde e à vida são primordiais no ordenamento jurídico brasileiro, devendo o Poder Público - nas três esferas de poder - adotar o Princípio do In Dubio Pro Salute em situações que representem risco à saúde humana - devendo-se incluir na questão a necessidade de se configurar o cenário de dúvida científica razoável:

CONSTITUCIONAL E ADMINISTRATIVO. MANDADO DE SEGURANÇA. PROGRAMA “MAIS MÉDICOS PARAO BRASIL”. MP 621/2013. IMPETRAÇÃO VOLTADA CONTRA ATO DO MINISTRO DA SAÚDE QUE INDEFERIU A INSCRIÇÃO DO DEMANDANTE. PRINCÍPIO IN DUBIO PRO SALUTE $[\ldots]$

2. Duas faces da mesma moeda, vida e saúde corporificam, na Constituição e na sistema infraconstitucional brasileiros, valores éticos, políticos e jurídicos

6 a dúvida sobre a natureza nociva de uma substância não deve ser interpretada como se não houvesse risco; todavia, a identificação do risco deve ser feita com base em informações científicas, com protocolos adequados (tradução original). 
primordiais e preeminentes do nosso Estado Social de Direito, cuja compreensão e respeito, por todos, espelham a imagem mais acabada daquilo que chamamos de civilização. Por isso mesmo, a atividade do legislador, administrador e juiz deve orientar-se pelo princípio in dubio pro salute [...] (BRASIL, 2013, s/p).

Seria oportuno, no intuito de sanar a dúvida exposta, que a ANVISA realizasse sua própria análise, conforme compromisso assumido por ela própria em 2015, após a divulgação dos resultados pela IARC. No entanto, o que se observa é uma reiterada omissão da agência, fato que é contundentemente verificado por ocasião da publicação do último programa de análise de resíduos de agrotóxicos em alimentos, no ano de 2016.

Conforme já mencionado em tópico anterior, ao realizar sua análise, a agência considerou apenas 232 produtos químicos, considerando como satisfatórios os resultados das amostras que não apresentaram resíduos das substâncias analisadas (42\%). Dentre as substâncias que não foram analisadas situa-se o glifosato, apesar de se tratar do agrotóxico mais utilizado no Brasil e a despeito da controvérsia acerca de seus efeitos nocivos à saúde humana. Como justificativa, a ANVISA informou que não realizou a análise do glifosato porque a metodologia seria distinta daquela empregada nas demais substâncias e que isso acarretaria na sobrecarga das atividades laboratoriais:

Os agrotóxicos glifosato e 2,4-D também se enquadram nessa situação. Devido à necessidade de metodologia específica, a análise dessas substâncias sobrecarrega a rotina laboratorial e deve-se, portanto, avaliar em quais casos a pesquisa é efetivamente imprescindível. A Anvisa pretende pesquisar esses agrotóxicos a partir dos próximos monitoramentos, priorizando-se as culturas em que essas substâncias são mais utilizadas (ANVISA, 2016, p. 21).

Observe-se, portanto, que mais uma vez a ANVISA se esquivou de sua obrigação e, diante da incerteza científica razoável no que diz respeito aos efeitos nocivos do glifosato à saúde humana, decidiu permanecer inerte, deixando o consumidor à própria sorte ao não adotar qualquer medida de precaução. Não exigiu nem o mínimo, que seria a prestação de advertências acerca dos possíveis riscos à saúde do consumidor, possibilitando o exercício da autodeterminação consciente, em conformidade com as exigências do CDC, da Lei 11.346/06 e do 
Decreto 5.098/04.

Em resumo, no ano de 2015 o IARC, que é uma agência intergovernamental ligada à Organização Mundial de Saúde, indicou que o glifosato tem potencial relação com doenças em seres humanos. Tal posicionamento não foi revisado pelo IARC posteriormente, porém, no ano de 2016 a FAO, que é outra agência vinculada à Organização Mundial de Saúde, afirmou ser improvável que a substância cause câncer em seres humanos em razão da dieta.

Essas manifestações contraditórias exaradas pela Organização Mundial de Saúde caracterizam perfeitamente um cenário de dúvida científica razoável, a justificar a aplicação de medidas de precaução. No entanto, frise-se novamente, fato é que apesar de se comprometer a realizar um estudo detalhado acerca dos efeitos nocivos da substância glifosato após a divulgação dos estudos do IARC, a ANVISA permaneceu omissa, não verificando a presença dos resíduos da substância nos alimentos disponibilizados ao consumidor e não avaliando a possibilidade efeitos nocivos à saúde humana.

\section{CONCLUSÃO}

É inegável que a Revolução Industrial trouxe benefícios para a sociedade, propiciando um aumento da produção capaz de atender a demanda sempre crescente. No entanto, como efeito colateral do progresso científico-tecnológico, tem-se a criação de riscos nem sempre perceptíveis a priori pela comunidade científica, que ameaçam o meio ambiente, a sadia qualidade de vida da população e a própria sobrevivência das gerações futuras.

Um desses graves riscos é consequência da intensa utilização de agrotóxicos a partir da Revolução Verde - iniciada na segunda metade do século XX -, uma vez que tais substâncias químicas podem causar intoxicação aguda ou crônica, sendo atualmente encontradas em qualquer parte do mundo, seja no meio biótico ou abiótico. Sua nocividade é amplamente reconhecida, inclusive pelo ordenamento jurídico brasileiro.

Existe uma íntima relação entre o controle de agrotóxicos e segurança alimentar, haja vista que esta última é objetivo nacional que somente será alcançado mediante a garantia individual de acesso a alimentos necessários para saciar a fome, com nutrientes suficientes à promoção do desenvolvimento humano sadio e que estejam, ademais, 
livres de contaminantes nocivos à saúde humana. Nesse sentido, fazse imprescindível uma análise eficiente da quantidade de resíduos de agrotóxicos presentes nos alimentos, bem como a adequada gestão dos riscos, aplicando-se, diante de dúvida científica razoável, as medidas de precaução pertinentes.

Contudo, ao se verificar os resultados da análise de resíduos realizada pela ANVISA, observa-se que a conclusão da agência, no sentido de que o nível de segurança alimentar no Brasil é satisfatório não corresponde à realidade. Isso porque ela própria informou a existência de riscos de intoxicação crônica e revelou ser incapaz de mensurá-los cientificamente. No que diz respeito à intoxicação aguda, os estudos foram omissos em relação a substâncias químicas utilizadas na produção agrícola, com especial destaque para o glifosato, cujos resíduos não foram analisados nas amostras selecionadas apesar de se tratar do agrotóxico mais utilizado no Brasil $-40 \%$ do total.

Aliás, o glifosato éalvo de grande controvérsia científica no âmbito internacional, haja vista que em 2015 a Organização Mundial de Saúde, via IARC, afirmou que a substância seria potencialmente cancerígena em seres humanos, havendo indícios também de que causaria danos ao DNA e a cromossomos de células humanas. No entanto, em 2016 mudou seu posicionamento, via FAO, para dizer ser improvável que o glifosato cause câncer em seres humanos por meio da dieta.

Tal situação caracteriza o que se compreende por dúvida científica razoável, a justificar a aplicação do princípio da precaução em relação à utilização do glifosato na produção agrícola brasileira, sendo possível, inclusive, a teor da regra contida na Lei 7.802/89, o cancelamento do seu registro e a proibição de seu uso.

Contudo, além de não ter sido aplicada qualquer medida de precaução em relação ao glifosato ou aos produtos contendo seus resíduos, a ANVISA abdicou de sua obrigação, não realizando estudos acerca do nível de resíduos de glifosato nos alimentos comercializados no Brasil e, tampouco, dos riscos associados.

Como agravante, destaca-se a tendência crescente de omitir informações sobre os alimentos, quando recentemente (17/04/2018) a Comissão de Meio Ambiente da Câmara dos Deputados aprovou o PLC 34/2015 que determina a retirada do triângulo amarelo com a letra $\mathrm{T}$ das embalagens dos alimentos transgênicos, potenciais disseminadores de resíduos de glifosato. 
Diante do cenário exposto, pode-se concluir que o Poder Público federal está sendo omisso em relação à gestão dos riscos associados ao glifosato, optando por permanecer inerte quanto à aplicação do princípio da precaução, de modo a inserir o consumidor num cenário de insegurança alimentar.

\section{REFERÊNCIAS}

AGÊNCIA INTERNACIONAL DE PESQUISA EM CÂNCER (IARC, em inglês). IARC Monographs Volume 112: evaluation of five organophosphate insecticides and herbicides. IARC, 2015. Disponível em: < https://www. iarc.fr/en/media-centre/iarcnews/pdf/MonographVolume112.pdf $>$. Acesso em: 19 de abril de 2018.

AGÊNCIANACIONALDEVIGILÂNCIASANITÁRIA(ANVISA). Nota: Carcinogenicidade de cinco agrotóxicos. ANVISA, 2015. Disponível em: $<\mathrm{http}$ //portal.anvisa.gov.br/noticias/-/asset_publisher/FXrpx9qY7FbU/ content/anvisa-esclarece-sobre-carcinogenicidade-de-cinco-substanciascomercializados-no-pais/219201/pop_up?inheritRedirect=false $>$. Acesso em: 19 de abril de 2018 .

AGÊNCIA NACIONAL DE VIGILÂNCIA SANITÁRIA (ANVISA). Programa de Análise de Resíduos de Agrotóxicos em Alimentos (PARA) - 2013 a 2015. ANVISA, 2016. Disponível em: <http://portal. anvisa.gov.br/documents/111215/0/Relat $\% \mathrm{C} 3 \% \mathrm{~B} 3$ rio+PARA+20132015_VERS\%C3\%83O-FINAL.pdf/494cd7c5-5408-4e6a-b0e55098cbf759f8>. Acesso em: 19 de abril de 2018.

AGÊNCIA NACIONAL DE VIGILÂNCIA SANITÁRIA (ANVISA). Índice Monográfico. ANVISA, 2017. Disponível em: $<$ http://portal.anvisa. gov.br/documents/111215/117782/G01\%2B\%2BGlifosato.pdf/6a549ab8990c-4c6b-b421-699e8f4b9ab4>. Acesso em: 19 de abril de 2018.

ANTUNES, Paulo de Bessa.The Precautionary Principle in the Brazilian Environmental Law. Revista Veredas do Direito: Direito Ambiental e Desenvolvimento Sustentável, Belo Horizonte, v. 13, n. 27, p. 63-88, 2016. Disponível em: <http://www.domhelder.edu.br/revista/index.php/ veredas/issue/view/41/showToc $>$. Acesso em: 19 de abril de 2018.

ASSOCIAÇÃO BRASILEIRA DE SAÚDE COLETIVA (ABRASCO). 
Dossiê ABRASCO: Um alerta sobre os impactos dos agrotóxicos na saúde. Rio de Janeiro / São Paulo: ABRASCO, 2015. Disponível em: $\quad<$ http://www.abrasco.org.br/dossieagrotoxicos/wp-content/ uploads/2013/10/DossieAbrasco_2015_web.pdf $>$. Acesso em: 19 de abril de 2018.

BECK, Ulrich. Sociedade de Risco: Rumo a uma outra modernidade/ Ulrich Beck; tradução de Sebastião Nascimento; inclui uma entrevista inédita com o autor - São Paulo: Editora 34, 2011 (2ª edição).

BEREND, Ivan T. An Economic History of Twentieth-Century Europe. / Ivan T. Berend. - Cambridge University Press, 2016. Disponível em: $<$ https://zodml.org/sites/default/files/\%5BIvan_T._Berend\%5D_An_ Economic_History_of_Twentieth-_0.pdf $>$. Acesso em: 19 de abril de 2018.

BOMBARDI, Larissa Mies, 1972 - Geografia do Uso de Agrotóxicos no Brasil e Conexões com a União Europeia / Larissa Mies Bombardi. - São Paulo: FFLCH -USP, 2017. Disponível em: < https://www.larissabombardi. blog.br/atlas2017>. Acesso em: 19 de abril de 2018.

BRASIL. Constituição da República Federativa do Brasil de 1.988. Diário Oficial da União, Brasília, 05 out. 1988. Disponível em: <http:// www.planalto.gov.br/ccivil_03/constituicao/constituicao.htm> Acesso em: 19 de abril de 2018.

BRASIL. Lei $\mathbf{n}^{\circ} \mathbf{7 . 8 0 2}$ de 11 jul. 1989. Dispõe sobre a pesquisa, a experimentação, a produção, a embalagem e rotulagem, o transporte, o armazenamento, a comercialização, a propaganda comercial, a utilização, a importação, a exportação, o destino final dos resíduos e embalagens, o registro, a classificação, o controle, a inspeção e a fiscalização de agrotóxicos, seus componentes e afins, e dá outras providências. Diário Oficial da União, Brasília, 18 ago. 1989. Disponível em: <http://www. planalto.gov.br/ccivil_03/leis/L7802.htm>. Acesso em: 19 de abril de 2018.

BRASIL. Lei $\mathbf{n}^{\circ} \mathbf{8 . 0 7 8}$ de 11 set. 1990. Dispõe sobre a proteção ao consumidor e dá outras providências. Diário Oficial da União, Brasília, 12 set. 1990. Disponível em: <http://www.planalto.gov.br/ccivil_03/leis/ L8078.htm>. Acesso em: 19 de abril de 2018. 
BRASIL. Lei $\mathbf{n}^{\circ} \mathbf{9 . 6 0 5}$ de 12 fev. 1998. Dispõe sobre as sanções penais e administrativas derivadas de condutas e atividades lesivas ao meio ambiente, e dá outras providências. Diário Oficial da União, Brasília, 13 fev. 1998. Disponível em: <http://www.planalto.gov.br/ccivil_03/leis/ L9605.htm>. Acesso em: 19 de abril de 2018.

BRASIL. Lei $\mathbf{n}^{\circ} \mathbf{9 . 7 8 2}$ de 26 jan. 1999. Define o Sistema Nacional de Vigilância Sanitária, cria a Agência Nacional de Vigilância Sanitária, e dá outras providências. Diário Oficial da União, Brasília, 27 jan. 1999. Disponível em: <http://www.planalto.gov.br/ccivil_03/leis/L9782.htm>. Acesso em: 19 de abril de 2018.

BRASIL. Decreto $\mathbf{n}^{0} \mathbf{4 . 0 7 4}$ de 04 jan. 2002. Regulamenta a Lei $\mathrm{n}^{\circ} 7.802$, de 11 de julho de 1989. Diário Oficial da União, Brasília, 08 jan. 2002. Disponível em: <http://www.planalto.gov.br/ccivil_03/decreto/2002/ d4074.htm>. Acesso em: 19 de abril de 2018.

BRASIL. Decreto $\mathbf{n}^{0} \mathbf{5 . 0 9 8}$ de 03 jun. 2004. Dispõe sobre a criação do Plano Nacional de Prevenção, Preparação e Resposta Rápida a Emergências ambientais com Produtos Químicos Perigosos - P2R2, e dá outras providências. Diário Oficial da União, Brasília, 04 jun. 2004. Disponível em: <http://www.planalto.gov.br/ccivil_03/_ato2004-2006/2004/decreto/ d5098.htm>. Acesso em: 19 de abril de 2018.

BRASIL. Lei $\mathbf{n}^{\circ} \mathbf{1 1 . 3 4 6}$ de 15 set. 2006. Cria o Sistema Nacional de Segurança Alimentar e Nutricional - SISAN com vistas em assegurar o direito humano à alimentação adequada e dá outras providências. Diário Oficial da União, Brasília, 28 mar. 2005. Disponível em: <http://www. planalto.gov.br/ccivil_03/_ato2004-2006/2005/lei/111105.htm>. Acesso em: 19 de abril de 2018.

BRASIL. Ministério do Desenvolvimento Agrário (MDA). Política Nacional de Desenvolvimento Rural Sustentável e Solidário (PNSRSS). Brasília, 2013. Disponível em: <http://www.mda.gov.br/pndrss/principal. pdf $>$. Acesso em: 19 de abril de 2018.

BRASIL. Ministério da Saúde. Política Nacional de alimentação e Nutrição (PNAN). Brasília, 2013. Disponível em: $<$ http://bvsms.saude. gov.br/bvs/publicacoes/politica_nacional_alimentacao_nutricao.pdf $>$. Acesso em: 19 de abril de 2018. 
BRASIL. Supremo TribunalFederal.AçãoDiretadeInconstitucionalidade $\mathbf{n}^{0} 3510$ - DF. Órgão Julgador: Tribunal Pleno. Relator: Ministro Ayres de Britto. Data do Julgamento: 29 de maio de 2008. Disponível em: <http:// www.stf.jus.br/portal/jurisprudencia/listarJurisprudencia.asp?s1=\%28351 0\%2ENUME $\% 2 \mathrm{E}+\mathrm{OU}+3510 \% 2 \mathrm{EACMS} \% 2 \mathrm{E} \% 29 \&$ base=baseAcordaos \&url=http://tinyurl.com/zxf6ocx>. Acesso em: 19 de abril de 2018.

BRASIL. Supremo Tribunal Federal. Recurso Extraordinário no 627189 - SP. Órgão Julgador: Tribunal Pleno. Relator: Ministro Dias Toffoli. Data do Julgamento: 23 de junho de 2017. Disponível em: <http://www.stf.jus. br/portal/jurisprudencia/listarJurisprudencia.asp?s1=\%28627189\%2ENU $\mathrm{ME} \% 2 \mathrm{E}+\mathrm{OU}+627189 \% 2 \mathrm{EACMS} \% 2 \mathrm{E} \% 29 \&$ base $=$ baseAcordaos\&url $=\mathrm{ht}$ tp://tinyurl.com/jz5ke9m>. Acesso em: 19 de abril de 2018.

BRASIL. Superior Tribunal de Justiça. Mandado de Segurança no 20457 DF. Órgão Julgador: Primeira Seção. Relator: Ministro Herman Benjamin. Data do Julgamento: 25 de setembro de 2013. Disponível em: $<$ https://ww2. stj.jus.br/processo/revista/inteiroteor/?num_registro $=201303173724 \& d t$ publicacao $=24 / 10 / 2016>$. Acesso em: 19 de abril de 2018 .

CARSON, Rachel. Primavera silenciosa / Rachel Carson ; [traduzido por Claudia Sant'Anna Martins]. - 1. ed. - São Paulo : Gaia, 2010.

DRUMOND, José Geraldo de Freitas. A Percepção Pública das Biotecnologias. In. ROMEO-CASABONA, Carlos María; SÁ, Maria Fátima Freire de. Desafios Jurídicos da Biotecnologia. - Belo Horizonte: Mandamentos, 2007.

FARIA, Neice Müller Xavier; FASSA, Anaclaudia Gastal; FACCHINI, Luiz Augusto. Intoxicação por agrotóxicos no Brasil: os sistemas oficiais de informação e desafios para realização de estudos epidemiológicos. Ciência \& Saúde Coletiva. Vol.12, p. 25-38, n ${ }^{\circ} .1$. Rio de Janeiro Jan./ Mar. 2007. Disponível em: <http://www.scielo.br/pdf/csc/v12n1/04.pdf $>$. Acesso em: 21 de abril de 2018.

FIOCRUZ, Fundação Oswaldo Cruz. Sistema Nacional de Informações Tóxico - Farmacológicas - SINITOX, 2016. Disponível em: <https:// sinitox.icict.fiocruz.br/>. Acesso em 20 de abril de 2018.

GARCIA, Denise Schmitt Siqueira. Dimensão Econômica da 
Sustentabilidade: uma análise com base na economia verde e na teoria do decrescimento. Revista Veredas do Direito: Direito Ambiental e Desenvolvimento Sustentável, Belo Horizonte, v. 13, n. 25, p. 133-153, 2016. Disponível em: <http://www.domhelder.edu.br/revista/index.php/ veredas/issue/view/39/showToc $>$. Acesso em: 20 de abril de 2018.

GOLLIN, Douglas; HANSEN, Casper Worm; WINGENDER, Asger. The Blades of Grass: The Impacto f Green Revolution / Douglas Gollin; Casper Worm Hansen; Asger Wingender. - University of Conpenhagen, 2016. Disponível em: <http://www.csae.ox.ac.uk/materials/papers/csae2016-30.pdf $>$. Acesso em: 19 de abril de 2018.

Instituto Nacional de Câncer (INCA). Posicionamento público acerca do uso de agrotóxicos. INCA, 2015. Disponível em: <http://www2. inca.gov.br/wps/wcm/connect/agencianoticias/site/home/noticias/2015/ inca_lanca_documento_e_promove_debate_sobre_maleficios_dos agrotoxicos>. Acesso em: 19 de abril de 2018.

MACHADO, Maria Olandina. Glifosato: A Emergência de uma Controvérsia Científica Global. 2016. 315 f. Tese (Doutorado). Universidade Federal de Santa Catarina, Florianópolis, 2016. Disponível em: <https://repositorio.ufsc.br/handle/123456789/169662>. Acesso em: 07 de novembro de 2017.

MACHADO, Paulo Affonso Leme - Direito Ambiental Brasileiro - $21^{\mathrm{a}}$ edição, revista, ampliada e atualizada, de acordo com as Leis 12.651, de 25.5.2012 e 12.727, de 17.10.2012 e com o Decreto 7.830, de 17.10.2012

MARQUES, Cláudia Lima. Diálogo das Fontes. In: BENJAMIN, Antônio Herman V. - Manual de direito do consumidor / Antônio Herman Benjamin, Cláudia L. Marques, Leonardo R. Bessa. - 7. ed. rev., atual. São Paulo: Editora Revista dos Tribunais, 2016.

MINISTÉRIO PÚBLICO FEDERAL (MPF). Diário do Ministério Público Federal Eletrônico. Ata de Audiência Pública: "Exposição aos Agrotóxicos e Gravames à Saúde e ao Meio Ambiente" (Primeiro Dia). Brasília, 2017. Disponível em: <http://bibliotecadigital.mpf.mp.br/ bdmpf/bitstream/handle/11549/97622/DMPF_EXTRAJUD_20170201. pdf? sequence $=1 \&$ is Allowed $=\mathrm{y}>$. Acesso em: $1 \overline{9}$ de abril de $20 \overline{18}$.

ORGANIZAÇÃO DAS NAÇÕES UNIDAS (ONU). Declaração do Rio sobre Meio Ambiente e Desenvolvimento de 1992. ONU, Brasil, 1992. Disponível em: <http:/www.onu.org.br/rio20/img/2012/01/rio92.pdf>. Acesso em: 19 de abril de 2018.

ORGANIZAÇÃO DAS NAÇÕES UNIDAS (ONU). Comentário Geral n ${ }^{\circ}$ 
12: O Direito Humano à Alimentação (art. 11). ONU, 1999. Disponível em: $\quad<$ http://www.sesc.com.br/mesabrasil/doc/Direito\%20humano\%20 $\%$ C3\%A $0 \% 20$ Alimenta $\%$ C3\%A7\%C3\%A3o-Seguran\%C3\%A 7 aalimentar.pdf>. Acesso em: 19 de abril de 2018.

ORGANIZAÇÃO DAS NAÇÕES UNIDAS (ONU). Report of the Special Rapporteur on the right to food. ONU, 2017. Disponível em: $<$ http:// www.pan-uk.org/site/wp-content/uploads/United-Nations-Report-of-theSpecial-Rapporteur-on-the-right-to-food.pdf $>$. Acesso em: 19 de abril de 2018.

ORGANIZAÇÃO DAS NAÇÕES UNIDAS PARA A ALIMENTAÇÃO E A AGRITULTURA (FAO, em inglês). Diretrizes Voluntárias em apoio à realização progressiva do direito à alimentação adequada no contexto da segurança alimentar nacional. FAO, 2004. Disponível em: <http://www. fao.org/3/b-y7937o.pdf > . Acesso em: 07 de novembro de 2017.

ORGANIZAÇÃO MUNDIAL DA SAÚDE (WHO). Joint FAO/WHO Meeting on Pesticides Residues. WHO, 2016. Disponível em: $<\mathrm{http} / /$ www.who.int/foodsafety/jmprsummary2016.pdf $>$. Acesso em: 19 de abril de 2018.

SENADO FEDERAL. Comissão de Meio Ambiente aprova fim de selo de identificação de produtos com transgênicos. 2018. Disponível em: $<$ https://www12.senado.leg.br/noticias/materias/2018/04/17/comissaode-meio-ambiente-aprova-fim-de-selo-identificacao-de-produtos-comtransgenicos>. Acesso em: 19 de abril de 2018.

VAZ, Paulo Afonso Brum. O Direito Ambiental e os agrotóxicos: responsabilidade civil, penal e administrativa / Paulo Afonso Vaz. - Porto Alegre: Livraria do Advogado Ed., 2006.

Artigo recebido em: 23/04/2018. Artigo aceito em: 09/05/2018.

\section{Como citar este artigo (ABNT):}

RIBEIRO, J. C. J.; GUSMÃO, L. C.; CUSTÓDIO, M. M. SEGURANÇA ALIMENTAR E AGROTÓXICOS: A situação do glifosato perante o princípio da precaução. Veredas do Direito, Belo Horizonte, v. 15, n. 31, p. 95-125, jan./abr. 2018. Disponível em: <http://www.domhelder.edu.br/ revista/index.php/veredas/article/view/1275>. Acesso em: dia mês. ano. 